\title{
Real-time PCR Detection of Dinophysis Species in Irish Coastal Waters
}

\author{
Siobhán Kavanagh \\ Rafael Salas
}

\author{
Claire Brennan \\ Josephine Lyons
}

\author{
Louise O'Connor \\ Joe Silke Majella Maher
}

\author{
Siobhán Moran
}

\begin{abstract}
Diarrhetic shellfish toxin-producing Dinophysis species occur in Irish coastal waters throughout the year. Dinophysis acuta and Dinophysis acuminata are the most commonly occurring species and are responsible for the majority of closures of Irish mussel farms. This study describes the development of a qualitative real-time poly-merase chain reaction (PCR) assay for identification of D. acuta and D. acuminata in Irish coastal waters. DNA sequence information for the D1-D2 region of the large ribosomal sub-unit (LSU) was obtained, following single-cell PCR of D. acuta and D. acuminata cells isolated from Irish coastal locations. PCR primers and hybridization probes, specific for the detection of D. acuta, w e $\mathrm{r}$ e designed for real-time PCR on the LightCyclerTM. The LightCycler ${ }^{\mathrm{TM}}$ software melt curve analysis programme determined that $D$. acuta was identified by a melt-peak at $61^{\circ}$ C, while D. acuminata cells produced a melt peak at $48^{\circ} \mathrm{C}$. The limit of detection of the real-time PCR assay was determined to be one to ten plasmid copies of the LSU D1-D2 target region for both species and one to five $D$. acuminata cells. Lugol's preserved water samples were also tested with the assay. The real-time PCR assay identified Dinophysis species in $100 \%$ of samples found to contain Dinophysis species by microscopy and had a greater than $90 \%$ correlation with light microscopy for identification of $D$. acuta and $D$. acuminata in the samples. The assay can identify and discriminate $D$. acuta and $D$. acuminata at low numbers in Irish waters and has the potential to add value to the Irish phytoplankton monitoring programme.
\end{abstract}

Keywords: Dinophysis

Hybridization probes

Diarrhetic shellfish poisoning LightCycler ${ }^{\mathrm{TM}}$ Real-time PCR

\section{Introduction}

The Irish aquaculture industry has progressed from the initial developments in the 1970s to become an important contributor to the national economy (Parsons et al. 2005). The shellfish industry was worth approximately $€ 60$ million to the Irish economy in 2006 (Browne et al. 2007). This valuable coastal industry has been affected in the past by harmful microalgae such as Dinophysis species. Several species of Dinophysis have been shown to produce dinophysistoxins (DTXs). The DTXs can potentially cause a syndrome known as diarrhetic shellfish poisoning (DSP), once shellfish that have accumulated these toxins are ingested by humans (Marcaillou et al. 2005). Dinophysis species can cause shellfish toxicity at cell concentrations as low as 200 cells/L (Lassus et al. 1985). The DTXproducing species Dinophysis acuta and Dinophysis acuminata can occur in Irish coastal waters throughout the year, primarily from late spring through early autumn, and the majority of closures of Irish mussel farms during the summer months are attributed to their presence.

In order to satisfy European Union (EU) legislative requirements pertaining to the production and export of shellfish (Council Directive 91/492), the Irish Marine 
Institute (MI) has put a programme in place to monitor the presence of harmful algal species and biotoxins in coastal waters. This monitoring programme currently relies on microscopic identification of phytoplankton species and biochemical analysis of shellfish tissue for toxins. Microscopic identification of phytoplankton species is time consuming and requires a high level of expertise (Penna et al. 2007). While Dinophysis may be identified to species level by light microscopy, it has been reported that the morphology of many species can be variable, complicating species identification (Edvardsen et al. 2003).

Nucleic acid-based diagnostic assays using a range of technologies have been developed and applied to monitor, identify and quantify toxic phytoplankton species (Scholin et al. 1997; Saito et al. 2002; Galluzzi et al. 2004; Coyne et al. 2005). Common molecular targets used in the assays include the ribosomal RNA (rRNA) genes, the internally transcribed (ITS) or non-transcribed spacer regions (Miller and Scholin 1998; Bowers et al. 2000; Asai et al. 2003; Sako et al. 2004). More recently, alternative molecular targets including microsatellite markers have been investigated for identification of phytoplankton species (Evans et al. 2004; Bornet et al. 2005). Assay formats include DNA probe-based methods such as fluorescence in situ hybridization (Scholin et al. 1997; Sako et al. 2004; John et al. 2005). More sophisticated DNA probe-based detection systems based on biosensor and microarray platforms have also been developed and applied to identify toxic species (Asai et al. 2003; Metfies et al. 2005; Ahn et al. 2006). Real-time polymerase chain reaction (PCR)-based assays have been developed to detect and/or quantify species including Alexandrium, Pfiesteria, Heterosigma, Lingulodinium and Chattonella (Bowers et al. 2000; Hosoi-Tanabe and Sako 2005; Moorthi et al. 2005; Coyne et al. 2005).

The objective of this study was to develop a rapid qualitative real-time PCR assay for the identification of the Dinophysis species, D. acuta and D. acuminata, in Irish water samples. Our approach was to design PCR primers and DNA hybridization probes to target a 270-bp region of the large ribosomal sub-unit (LSU; D1-D2) rDNA for real-time PCR on the LightCycler ${ }^{\mathrm{TM}}$. HybProbe assays utilise two fluorescently labelled probes that hybridise adjacently on the singlestranded nucleic acid target, typically one to five bases apart, during the primer-annealing phase of the PCR. Excitation energy is transferred between the probes by fluorescent resonance energy transfer, and this is read by the LightCycler $^{\mathrm{TM}}$ (Anon 2000). Melt-peak analysis is performed after PCR amplification to differentiate binding of the probes with target sequences from binding with non-target sequences. The application of the real-time PCR assay for the identification of $D$. acuta and D. acuminata in preserved Irish water samples from the MI phytoplankton monitoring programme was investigated and correlated with light microscopy results.

\section{Materials and Methods}

Samples

Net haul samples of seawater containing D. acuta and $D$. acuminata cells were taken from Killary Harbour and Bantry Bay and preserved with Lugol's iodine for singlecell isolation (Fig. 1). Two Lugol's iodine preserved 25-ml MI monitoring programme samples from Drumcliff Bay (Sligo) and Sheephaven Bay (Donegal) containing D. acuta and D. acuminata cells were also used in the development of the real-time PCR assay (Fig. 1). Twenty preserved seawater samples containing D. acuta and D. acuminata cells were received from the Fisheries Research Services (FRS), Marine Laboratory (Aberdeen, Scotland), for singlecell isolation. Fifty-five preserved samples from Irish coastal sites, examined by light microscopy for Dinophysis species (Supplementary Table 1), were tested with the realtime PCR assay. Thirty-three samples contained Dinophysis cells, with numbers of $D$. acuta and D. acuminata ranging from one to eight cells in $25 \mathrm{ml}(40-320$ cells/L). Other phytoplankton species used to evaluate the specificity of the real-time PCR assay (Supplementary Table 2) included cultures of phytoplankton being maintained at the MI phytoplankton lab, DNA extracts of Alexandrium species available from a previous study and phytoplankton cells isolated from samples or present in DNA extracts of MI monitoring programme samples.

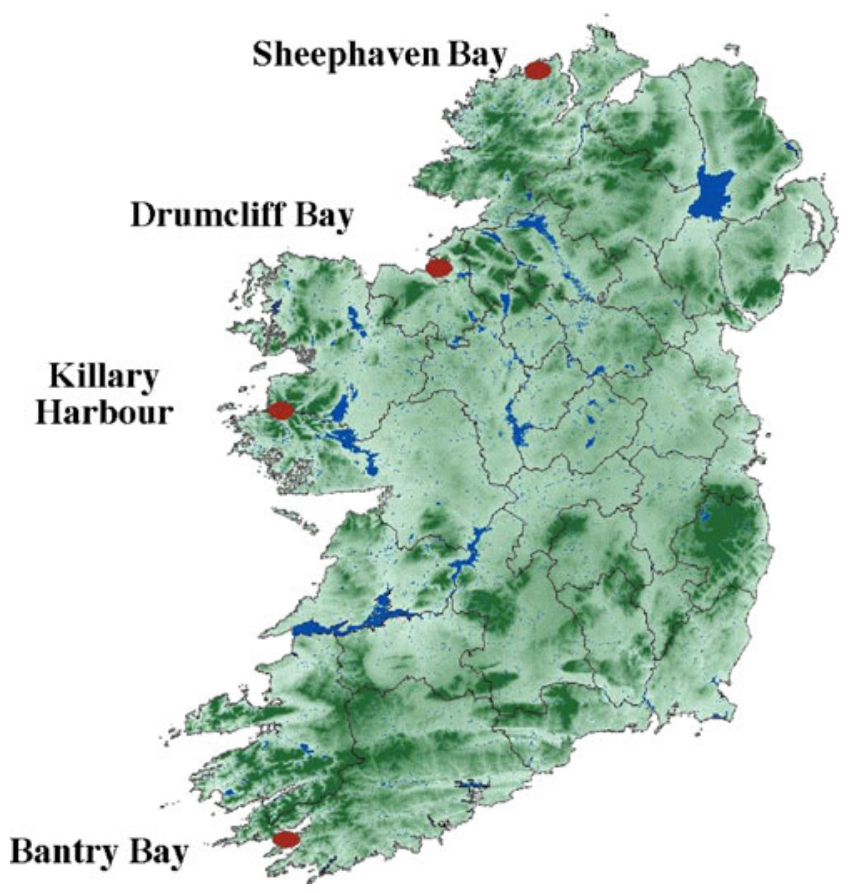

Fig. 1 Map of Irish sampling sites for single cell isolation of Dinophysis acuta and Dinophysis acuminata 
Table 1 Polymerase chain reaction (PCR) primers and hybridization probes designed for the Dinophysis real-time PCR assay

\begin{tabular}{lll}
\hline Oligonucleotide & Target gene & Sequence \\
\hline DIN_F & rDNA LSU & 5'-ATGAGGGAAAGGTGAAAA \\
DIN_R & rDNA LSU & 5'-CTTACGCACAAGCATAAC \\
LSU_1 & rDNA LSU & 5'-GGATTGGTTGCTGCCACAAC \\
& & GC-Fl \\
LSU_2 & rDNA LSU & 5'-LC Red640-AGTGTGATGGCGA \\
& & TGTGTGAATT
\end{tabular}

Probe LSU_1 was labelled with Fluorescein. Probe LSU_2 was labelled with the LightCycler specific dye LC Red640

\section{Single-Cell PCR and DNA Sequencing}

Dinophysis cells were isolated from preserved seawater samples under an inverted light microscope (Nikon) at $\times 40$ magnification by capillary isolation (Guillard 1973). Cells were washed at least once in sterile PCR grade water before final isolation in approximately $3 \mu \mathrm{l}$ in a PCR tube. Singlecell PCR was performed on Dinophysis cells (D. acuta and D. acuminata) using the LightCycler ${ }^{\mathrm{TM}}$ (Roche Diagnos-tics, Germany) in glass capillaries (Roche) in a final volume of 20 $\mu l$. The final optimised reaction conditions were as follows: $2 \mu \mathrm{l}$ of the 10X LightCycler ${ }^{\mathrm{TM}}$ FastStart DNA master hybridization probe mix, $4 \mathrm{mM} \mathrm{MgCl}_{2}$ and $25 \mathrm{pmol} / \mu \mathrm{l}$ of the primers D1R and D2C (Edvardsen et al. 2003). The thermocycling conditions included an initial hot start step at $95^{\circ} \mathrm{C}$ for $10 \mathrm{~min}$ followed by 45 cycles of denaturation at $95^{\circ} \mathrm{C}$ for $15 \mathrm{~s}$, annealing at $50^{\circ} \mathrm{C}$ for $15 \mathrm{~s}$ and extension at $72^{\circ} \mathrm{C}$ for $15 \mathrm{~s}$. The temperature transition rate was $20^{\circ} \mathrm{C} / \mathrm{s}$. PCR products were analysed on a $0.8 \%$ agarose gel stained with $10 \mu \mathrm{g} / \mathrm{ml}$ ethidium bromide and visualised under an ultraviolet (UV) light source using the Bio Profil Imaging system. The LSU D1-D2 region PCR products generated from single-cell PCR were sequenced in both directions by an external sequence service provider (Sequiserve, Berlin, Germany).

\section{DNA Extraction}

In this study, DNA extraction was performed on a range of different sample types. Lugol's iodine preserved samples (25 $\mathrm{ml}$ ) from the MI phytoplankton monitoring programme were filtered through $1-\mu \mathrm{M}$ cellulose nitrate filters (What-man, Dassel, Germany) using a 50-ml syringe. Individual filters were placed in microcentrifuge tubes using a sterile forceps. Biomass was washed from the filters by addition of $500 \mu \mathrm{l}$ of cetyl trimethyl ammonium bromide (CTAB) buffer $(1 \%$ CTAB, $100 \quad \mathrm{mM}$ Tris- $\mathrm{HCl}, 20 \mathrm{mM}$ ethylenediaminetetraacetic acid and $1 \mathrm{M} \mathrm{NaCl}$ ) and vortexed for three cycles of $15 \mathrm{~s}$. The filters were removed, and DNA extraction was performed on the biomass using the
DNeasy ${ }^{\circledR}$ Plant Minikit (Qiagen, Valencia, CA, USA) according to the manufacturer's instructions. DNA was extracted from phytoplankton species cultures as follows. Twenty-five millilitres of Pseudo-nitzschia species, Prorocentrum dentatum and Gymnodinium cf. species cultures were concentrated by filtration as previously described. DNA was extracted from the $P$. dentatum and Gymnodinium cf. species cells using the using DNeasy ${ }^{\circledR}$ Plant Minikit (Qiagen, Valencia, CA, USA) according to the manufacturer's instructions. DNA was extracted from Pseudonitzschia species cells using the Doyle and Doyle method (1987) with an initial liquid $\mathrm{N}_{2}$ freeze thaw pre-extraction step (five cycles). For D. acuminata cells (100, 50, 20, 10 and 5 cells) isolated from the samples received from FRS, DNA extraction was performed on a volume of $100 \mu \mathrm{l}$, using the DNeasy ${ }^{\circledR}$ Plant Minikit (Qiagen, Valencia, CA, USA). All DNA extracts were stored at $-20^{\circ} \mathrm{C}$.

\section{Design of PCR Primers and Hybridization Probes}

The D. acuta $(n=5)$ and D. acuminata $(n=15)$ rDNA LSU D1-D2 region sequences from Irish coastal waters were analysed using the BLAST 2.0 (Gapped BLAST; Altschul et al. 1997) programme on the National Center for Biotechnology Information website (www.ncbi.nlm.nih.gov) to search for sequences in the databases that showed significant similarity. Similarity percentages were calculated after manual alignment of the sequences with the closest relative from the BLAST output.

Alignments of rDNA sequences for Irish D. acuta and D. acuminata were performed with all available LSU Dinophysis species sequences downloaded from GenBank, using Clustal X (Thompson et al. 1997). Primers (DIN_F and DIN_R) and hybridization probes (LSU_1 and LSU_ 2) were designed for the real-time PCR assay from the alignments (Table 1). LSU_1 was labelled with fluorescein, and LSU_2 was labelled with the LightCycler specific dye LC Red640. The primers and hybridization probes were synthesised by TIB Molbiol (Berlin, Germany). The primers were designed to amplify a 270 -bp product internal to the LSU D1-D2 region. The hybridization probes were designed to be complimentary to a 43-bp sequence within the target region of Irish $D$. acuta isolates. The hybridization reporter probe (LSU_2) was designed to have a 4-bp mismatch to Irish D. acuminata isolates (Fig. 2).

\section{Cloning}

Conventional PCR amplification of the 270-bp target region for the real-time PCR assay was performed on $D$. acuta and D. acuminata single cells. PCR amplification was performed in a final volume of $50 \mu \mathrm{l}$ containing the following: 10X PCR buffer (Promega, Fitchburg, WI, 
Fig. 2 Multiple alignment of representative sequences, from members of the Dinophysis genus, in the LSU D1-D2 real-time polymerase chain reaction assay region. HybProbe pair specific for Dinophysis acuta are highlighted

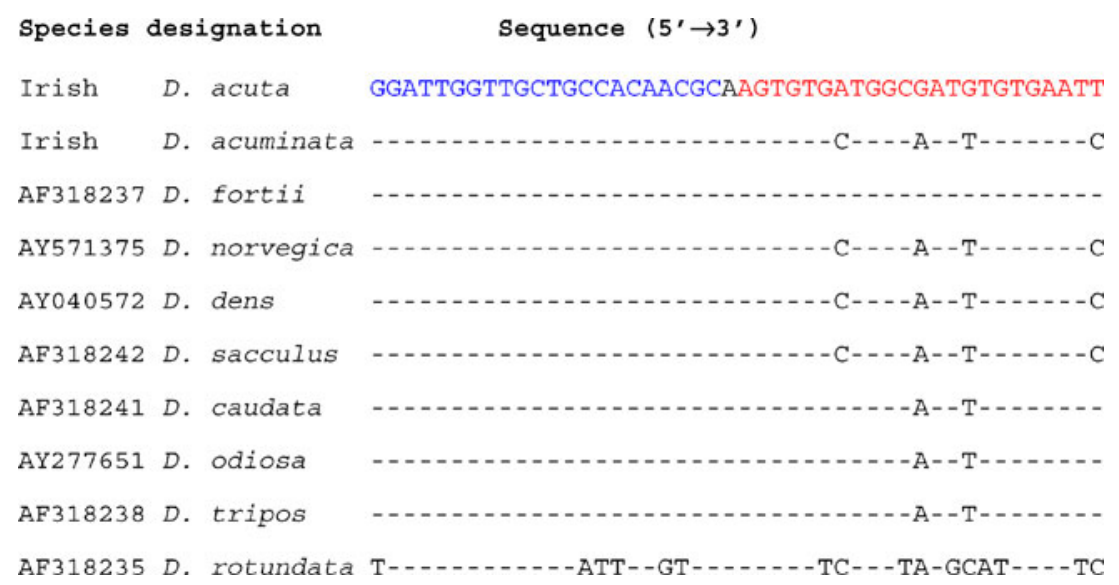

USA), $200 \mu \mathrm{M}$ dNTPs, $1.5 \mathrm{mM} \mathrm{MgCl}_{2}, 2 \mathrm{U}$ Taq DNA polymerase (Promega, Fitchburg, WI, USA) and $12.5 \mathrm{pmol} / \mu \mathrm{l}$ of each primer (DIN_F/DIN_R), and the reaction was made up to a final volume of $50 \mu \mathrm{l}$ with PCR grade water. Thermocycling was performed on the MJ Research machine (MJ Research, Bio-Rad Laboratories Inc., Hercules, CA, USA) using the following conditions: an initial denaturation at $95^{\circ} \mathrm{C}$ for $5 \mathrm{~min}$, followed by 30 cycles of $94^{\circ} \mathrm{C}$ for $1 \mathrm{~min}, 55^{\circ} \mathrm{C}$ for $45 \mathrm{~s}$ and $72^{\circ} \mathrm{C}$ for $1 \mathrm{~min}$, followed by a final extension step at $72^{\circ} \mathrm{C}$ for $10 \mathrm{~min}$. PCR products were analysed on a $0.8 \%$ agarose gel containing $10 \mu \mathrm{g} / \mathrm{ml}$ ethidium bromide and visualised under a UV light source using the Bio Profil Imaging system (Vilber Lourmat, France). The PCR products were cloned into the plasmid vector $\mathrm{pCR}^{\circledR}$ 2.1-TOPO (Invitrogen, Carlsbad, CA, USA) according to the manufacturer's instructions. Recombinant plasmids were identified by blue/white colour selection on Luria Broth (LB) agar plates containing $50 \mu \mathrm{g} / \mathrm{ml}$ of ampicillin and $40 \mu \mathrm{g} / \mathrm{ml}$ of X-gal. White colonies were picked off the agar plate and streaked onto LB agar plates containing ampicillin $(40 \mu \mathrm{g} / \mathrm{ml})$. Small-scale plasmid preparations were performed on colonies from the plates using the Qiagen QIAprep spin miniprep kit, according to the manufacturer's instructions. PCR amplification was carried out as described above using the DIN_F and DIN_R primers, to confirm the presence of the insert. The PCR products were sequenced (Sequiserve, Berlin, Germany) to confirm the identity of the inserts from the clones.

\section{Real-time PCR Assays}

Real-time PCR amplification was performed using the reagents and thermocycling conditions previously described for single-cell PCR on the LightCycler ${ }^{\mathrm{TM}}$ (Roche Diagnostics, Germany) with the exception that $0.2 \mu \mathrm{M}$ of each hybridization probe (LSU_1 and LSU_2) and $12.5 \mathrm{pmol} / \mu \mathrm{l}$ of the primers (DIN_F and DIN_R) were included in the reaction mix. Two microlitres of template was used (DNA extracts from wild samples, DNA extracts from phytoplankton cultures or single-cell isolates) for each reaction. Fluorescence was measured at $640 \mathrm{~nm}$ (F2/F1 channel) at the end of each annealing phase of the PCR. The melt-curve analysis programme was carried out as follows: $95^{\circ} \mathrm{C}$ for $60 \mathrm{~s}, 40^{\circ} \mathrm{C}$ for $60 \mathrm{~s}$ and increased to $80^{\circ} \mathrm{C}$ at $0.1^{\circ} \mathrm{C} / \mathrm{s}$, with the fluorescence signal being continuously monitored.

\section{Results and Discussion}

\section{Assay Design}

The LSU D1-D2 region from 20 single-cell isolates of $D$. acuta $(n=5)$ and $D$. acuminata $(n=15)$ taken from four Irish coastal sites were sequenced (Fig. 1). No intra-species sequence variation was observed amongst the Irish $D$. acuminata or D. acuta isolates, respectively. Comparative analysis of the Irish $D$. acuta sequence data with the $D$. acuta LSU D1-D2 sequences available in the GenBank revealed 99-100\% similarity with D. acuta isolates from the Scottish coastline (AY277642, AY277648, AY277647, AY277646 and AY259236). The LSU D1-D2 region of Irish D. acuminata isolates had $100 \%$ similarity to the LSU D1-D2 region in D. acuminata strains from France, UK and South Africa (AY040579, AY040578, AY040577, AY040574 and AF318246).

Alignments of the sequences from Irish D. acuta and $D$. acuminata with LSU D1-D2 region sequence information available for other Dinophysis species was performed to design the hybridization probes and primers for the realtime PCR assay (Table 1). Based on in silico analysis (Blast $\mathrm{N}$ and Clustal $\mathrm{X}$ ), the primers were designed for the amplification of members of the Dinophysis genus for which sequence information was available in GenBank. The reporter probe for the real-time assay was designed to be specific for $D$. acuta and to include $4 \mathrm{bp}$ differences between $D$. acuta and D. acuminata in the 270-bp target region. Sequence differences with other Dinophysis species in the reporter probe region included $2 \mathrm{bp}$ for Dinophysis 
caudata (AF318241, AF318240 and AY040584) Dinophysis odiosa (AY277651 and AY259241) and Dinophysis tripos (AF318238, AY259242 and AY040585), 4 bp for Dinophysis sacculus (AF318242, AY040583, AY040582, AY040581 and AY040580), Dinophysis dens (AY040572 and AY040571) and Dinophysis norvegica (AY571375, AY259239, AY259238, AJ506978, AF414687, AF414686 and AF414688) and 10 bp for Dinophysis rotundata (AF318235 and AJ506979; Fig. 2).

After real-time PCR amplification, the melt curve analysis algorithm of the LightCycler ${ }^{\mathrm{TM}}$ software was applied to analyse the Dinophysis species PCR products. Melt-peak analysis of the $D$. acuta reporter probe consistently yielded a melt-peak at $61^{\circ} \mathrm{C}$ for a plasmid containing the assay target region for $D$. acuta, for single cells of $D$. acuta isolated from different Irish coastal locations and for DNA extracts from wild samples identified by light microscopy to contain D. acuta cells (Fig. 3). Melt peak analysis of the $D$. acuminata PCR products with the $D$. acuta reporter probe produced melt peaks at $48^{\circ} \mathrm{C}$, approximately $13^{\circ} \mathrm{C}$ lower than for the $D$. acuta PCR product. This melt peak temperature for $D$. acuminata was confirmed when a plasmid containing the 270-bp target region for $D$. acuminata was included in the real-time PCR assay. D. acuminata single cells isolated from different coastal locations and DNA extracts from wild samples identified by light microscopy to contain $D$. acuminata cells also produced melt peaks at $48^{\circ} \mathrm{C}$ with the real-time PCR assay (Fig. 3). Therefore, the Dinophysis species realtime PCR assay developed in this study can simultaneous detect and discriminate $D$. acuta and D. acuminata.

An advantage of hybridization probe technology is the potential to detect and distinguish between two or more species with a single probe set, through the application of melt-peak analysis. In addition to the detection and discrimination of $D$. acuta and $D$. acuminata, the real- time PCR assay has the potential to detect other Dinophysis species based on melt-peak analysis. However, due to sequence similarity within the LSU D1-D2 region between certain species, for example $D$. acuminata, $D$. sacculus, $D$. dens and D. norvegica (Fig. 2), these species will be detected and discriminated from D. acuta by the assay but may not be distinguished from each other. In addition, comparison of LSU D1-D2 sequence information available for Dinophysis fortii in GenBank $(n=2)$ reveals $100 \%$ similarity with $D$. acuta within this region and, therefore, $D$. fortii may not be discriminated from D. acuta by the real-time PCR assay. As cells or DNA was not available for these Dinophysis species, this could not be tested experimentally.

Currently, 11 members of this genus are confirmed to produce toxins that are implicated in DSP including okadaic acid (OA), DTX1 and pectenotoxin-2 (PTX2) (Zingone 2005). D. acuta and D. acuminata are the two most commonly occurring toxic species in Irish coastal waters. Of the other Dinophysis species listed in Fig. 2, D. sacculus, a known producer of OA, has not been observed to date in MI phytoplankton monitoring programme samples. This species is common along the Mediterranean and North Atlantic coasts but has rarely been recorded outside this area (Zingone 2005). D. norvegica, a known producer of DTX1 and OA, and D. dens have only comprised $1 \%$ and $5 \%$, respectively, of total Dinophysis species observed from 2003 to 2009. D. norvegica is widely distributed in cold to temperate coastal waters of the Northern Hemisphere, with toxic strains known from Europe and North America. D. dens has a worldwide distribution but is not on the reference list of toxic Dinophysis species from the International Oceanographic Commission (IOC) website. The occurrence of $D$. fortii, a known producer of OA, DTX1 and PTX2, in Irish coastal waters is rarely reported, comprising less than $1 \%$ of Dinophysis species observed since 2003. D. fortii is widely

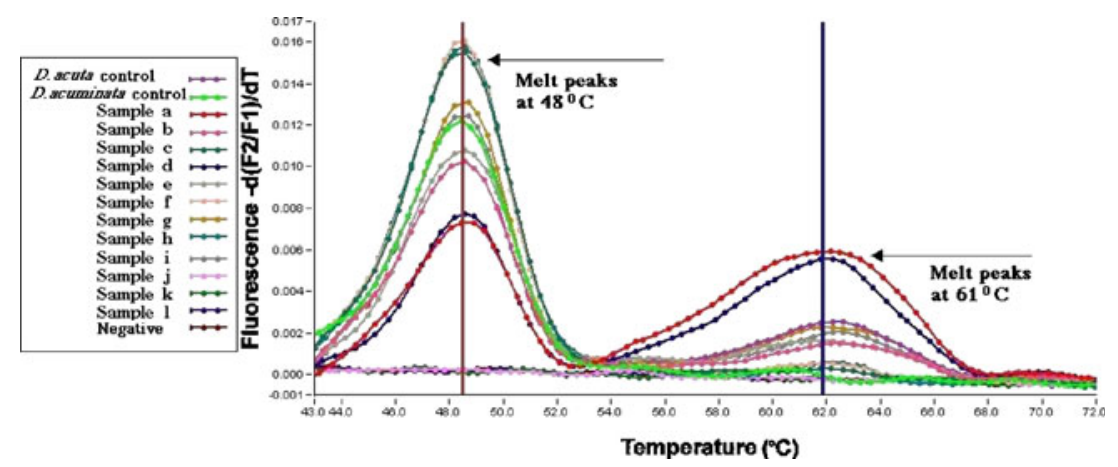

Fig. 3 Real-time polymerase chain reaction assay for the detection of Dinophysis species. Two positive controls are included, plasmids containing the target region from Dinophysis acuminata and from Dinophysis acuta, respectively. Melt peak results for the following DNA extracts from Marine Institute monitoring programme samples are shown. Sample $a$ : Bantry Bay N; sample $b$ : Bantry Bay; sample $c$ :
Kilkieran Bay; sample $d$ : Bantry Bay N; sample $e$ : Bantry Bay; sample $f$ : Clare; sample $g$ : Ballinakill Hbr.; sample $h$ : Mulroy Bay; sample $i$ : Donegal Bay; sample $j$ : Kerry; sample $k$ : Bantry Bay; sample $l$ : Mannin Bay. Cell numbers for each species and sample are included in Supplementary Table 1. The hybridization probes yielded melt peaks at $48^{\circ} \mathrm{C}$ for $D$. acuminata and $61^{\circ} \mathrm{C}$ for D. acuta 
distributed in cold temperate waters worldwide but is also found in subtropical to tropical areas. D. rotundata and D. tripos, both known to produce DTX1, comprised $9 \%$ and $0.4 \%$ of total Dinophysis species observed in MI monitoring programme samples. D. rotundata is a cosmopolitan species widely distributed in cold and warm waters, but only Japanese strains of this species have been found to produce DSP toxins. There are no specific records of DSP outbreaks involving $D$. tripos. It is widely distributed in tropical and temperate waters of both hemispheres and occasionally appears in colder areas. Of the two remaining Dinophysis species from Fig. 2, D. caudata is a producer of OA and PTX-2, and D. odiosa does not occur on the IOC reference list of toxic Dinophysis species. D. caudata is widely distributed in neritic waters of temperate to tropical areas in both hemispheres with toxic strains reported from Europe, America and Asia. D. odiosa has been isolated from Scottish coastal waters (Hart et al., unpublished data). Neither species has appeared in MI monitoring programme reports to date.

There is some evidence to suggest that changes in sea temperature may affect the geographical distribution of phytoplankton species (Behrenfeld et al. 2006; Dybas 2006; Gómez 2008) and therefore may result in increased frequency of occurrence of other toxic Dinophysis species in Irish coastal waters. The assay has the potential to detect these species, but due to the sequence similarities discussed earlier, all species may not be discriminated from each other. The real-time PCR assay developed in this study was designed for use in Irish coastal waters based on current monitoring concerns and in this context is capable of detecting and discriminating the two most commonly occurring toxic Dinophysis species.

Previous studies have reported the development of PCRbased assays for the detection of Dinophysis species, with detection limits of ten copies for ITS-5.8S rDNA cloned sequence of Dinophysis species (Penna et al. 2007) and 30 cells/L of $D$. acuminata (Puel et al. 1998). To the best of our knowledge, this is the first report on the development of a real-time PCR assay incorporating hybridization probe technology for identification of Dinophysis species.

\section{Assay Specificity}

The specificity of the assay for detection and discrimination of D. acuta and D. acuminata was performed as described previously, and the assay was observed to consistently produce melt peaks at $61^{\circ} \mathrm{C}$ for $D$. acuta and $48^{\circ} \mathrm{C}$ for $D$. acuminata (Fig. 3). No other Dinophysis species cells were available from the MI phytoplankton monitoring programme samples for testing with the real-time PCR assay. DNA extracted from cultures of Pseudo-nitzschia, Alexandrium, Phalacroma and Prorocentrum (Supplementary Table 2) d i d not produce fluorescent signals or melt peaks with the $D$. acuta reported probe, when included as templates in the real-time PCR assay. The suitability of these DNA extracts for P C R w a s verified b y mplification with D 1 - D 2 region primers (D1R and D2C, Edvardsen et al. 2003) a $\mathrm{n} \mathrm{d}$ agarose gel electrophoresis. For the other species listed in Supplementary Table 2, pure cultures were not available, and they were tested with the assay as total phytoplankton community biomass present in the samples. When DNA was extracted from these samples and included in the realtime PCR assay, no amplification signals or melt peaks were obtained.

\section{Analytical Sensitivity}

To determine the theoretical detection limit of the real-time PCR assay, serial dilutions of plasmids $\left(10^{8}\right.$ to one copy) containing the 270-bp LSU D1-D2 target region from $D$. acuta and D. acuminata were included as templates in the real-time PCR assay. Detection limits of less than ten copies of the plasmid were consistently achieved for both targets. To determine the detection limit of the assay for D. acuta and D. acuminata cells, DNA extracted from a range of different cell numbers of $D$. acuminata cells $(100,50,25$, ten, and five cells) was tested in the real-time PCR assay. Sufficient numbers of $D$. acuta cells were not available to allow the detection limit for $D$. acuta cells to be determined. DNA was extracted from replicate $(n=3)$ D. acuminata cells (50 to five cells) and one sample of 100 cells following filtration using the DNeasy ${ }^{\circledR}$ Plant Minikit. Three single-cell isolates, representing a one-cell concen-tration, were also included as templates in the real-time PCR assay. Amplification signals and melt peaks at $48^{\circ} \mathrm{C}$ were obtained for DNA from 100 to five cells for all replicates and for one of the three $D$. acuminata single cells included in the assay. Two out of the three $D$. acuminata single cells did not amplify. This suggests that the detection limit for $D$. acuminata cells is between one and five cells. This is consistent with detection limits reported for real-time PCR assays for other toxic phytoplankton species (Galluzzi et al. 2004; Coyne et al. 2005; Hosoi-Tanabe and Sako 2005; Moorthietal 2005.

These

researchers developed quantitative real-time PCR (qPCR) assays using plasmid-encoded internal reference standard, serial dilu-tions of plasmids containing the real-time PCR test target region or serial dilutions of known cells numbers to generate standard curves for qPCR. Evaluations of the qPCR assays for estimation of cells abundances were reported to show good correlation to microscopy-based counting (Galluzzi et al. 2004; Coyne et al. 2005; Hosoi-Tanabe and Sako 2005; Moorthi et al. 2005). In this study, we found that serial dilutions of plasmids containing the assay target inserts for D. acuta and D. acuminata produced 
the typical three cycle difference $(\mathrm{Ct})$ values expected for tenfold serial dilutions of templates in real-time PCR. However, across the range of $D$. acuminata cell concentrations from 100 to one cell, the $\mathrm{Ct}$ values varied by less than one cycle. Therefore, it was not possible to generate a standard curve based on known cells numbers for application in qPCR. The generation of standard curves based on copy number of the cloned D. acuta and D. acuminata targets would have been possible. However, as the copy number of the rRNA LSU in $D$. acuta and $D$. acuminata has not been published to date, it would not be possible to relate plasmid copy number to cell abundances for $D$. acuta and D. acuminata. Until recently, the lack of in vitro culture methods for Dinophysis species represented a major limitation for development of molecular and other diagnostic assays for these species. For this study, we were relying on the microscopic isolation of cells from preserved samples to generate the range of $D$. acuminata cell concentrations. Park et al. (2006) reported on the first successful establishment of an in vitro culture of $D$. acuminata, with cell numbers reaching a concentration of about 2,400 cells $/ \mathrm{ml}$. The successful culturing of many Dinophysis species in order to generate sufficient cells numbers to allow for the development of a qPCR assay may be possible in the near future. This would also enable the investigation of a range of cell lysis and DNA extraction methods without the requirement for laborious cell isolations.

\section{Testing of Wild Samples}

Fifty-five MI preserved phytoplankton monitoring programme samples were evaluated with the Dinophysis real-time PCR assay. These samples were analysed by light microscopy, and 33 of the samples were determined to contain between one and eight cells of $D$. acuta and $D$. acuminata in $25 \mathrm{ml}$, with 12 samples containing only one cell of either species (Supplementary Table 1). Based on microscopic analysis, $15 \%$ of the samples contained D. acuta, and $96 \%$ of the samples contained $D$. acuminata while $12 \%$ of the samples contained both Dinophysis species. The real-time PCR assay detected the presence of a Dinophysis species in all samples reported to contain Dinophysis cells. D. acuminata wa s i d e $\mathrm{nt}$ i f i e d b y the re a 1 - time PCR assay in DNA extracts from all samples reported to contain $D$. acuminata by microscopy. D. acuta and $D$. acuminata specific-melt peaks were obtained in the realtime PCR assay for the four samples reported to contain both species by light microscopy. Additionally, the presence of $D$. acuta was detected by the real-time PCR assay in the only sample reported to contain $D$. acuta alone by light microscopy. For 30 samples, there was $100 \%$ correlation between the microscopic and real-time PCR results. In three of the 33 samples, D. acuta was detected by the real-time PCR assay where it was not reported by light microscopy. Detection of Dinophysis species by PCR assay in preserved samples, which were not identified by microscopic analysis, was reported by Penna et al. (2007). They suggested that the samples might have contained cells that were below the detection limit of microscopy or that may not have been a dominant component of the natural phytoplankton community. Microscopic analysis of samples by the MI monitoring programme is performed on the total $25 \mathrm{ml}$ of sample. It is possible that the real-time PCR assay may have detected DNA from degraded or broken cells in these three samples that would not have been detected by light microscopy.

Twenty-two samples that were negative for Dinophysis species after light microscopy were also negative using the real-time PCR assay. These samples contained a range of other phytoplankton species (Supplementary Table 2). When DNA extracted from these Dinophysis negative samples was included in the real-time PCR assay, no fluorescent signals or melt peaks were obtained, indicating that the assay did not cross-react with these indigenious phytoplankton species.

Overall, there was more than $90 \%$ correlation between methods. The real-time PCR assay correctly identified a Dinophysis species in all samples containing one cell. This suggests that the detection limit of the real-time PCR assay for D. acuta and D. acuminata in wild samples is one cell. Some studies have reported a decreased sensitivity of detection of phytoplankton nucleic acids in samples preserved with Lugol's iodine (Bowers et al. 2000; HosoiTanabe and Sako 2005), but this was not evident in this study. Phytoplankton monitoring is regulated by EU legislation, hygiene regulation $(854 / 2004)$. The legislation states that national monitoring programmes must periodically sample for toxic phytoplankton, taking into account potential periods of toxicity. Since May 2005, the MI monitoring programme has used the Ütermohl cell counting method to monitor for toxic phytoplankton species. This method has proven to be the most reliable for the identification and enumeration of phytoplankton (Godhe et al. 2007) and has been validated to ISO 17025 standard by the Irish National Accreditation Board (INAB).

The real-time PCR assay described in this study is currently being used to compliment the MI phytoplankton monitoring programme. Standard Operating Procedures were generated for each stage of the method as part of the MI Quality system, and it is intended that the method will be validated to ISO 17025 standard in the future. An important consideration for the application of real-time PCR assays to environmental monitoring is the inclusion of controls to assess PCR performance (Hiney 1999). These include use of appropriate positive and negative controls 
and engineered internal standards or Internal Control (IC; Shariff et al. 1999). The design and testing of an IC for the Dinophysis assay was initiated as part of the PHYTOTEST project, and this will be incorporated into the validation process. A number of reports have been published outlining methods for the design of ICs and highlighting other important considerations for PCR-based diagnostic tests (Hoorfar et al. 2004). Additionally, INAB (http://www. inab.ie) have well-defined specifications and requirements that PCR-based tests must adhere to in order to obtain EU regulatory approval.

\section{Conclusions}

We have developed a qualitative real-time PCR assay incorporating hybridization probe technology for the detection of Dinophysis species in Irish coastal waters. The assay was successfully applied to wild samples and detected and discriminated between $D$. acuta and $D$. acuminata. There was $100 \%$ detection of Dinophysis species in samples by the assay, with a detection limit of one cell. Greater than $90 \%$ correlation was observed with light microscopy results for species identification. Analysis of samples by light microscopy requires settling, prior to examination by a trained taxonomist, which is time consuming. The timeframe for the real-time PCR assay is approximately $3 \mathrm{~h}$ from receipt of samples to result. The assay developed in this study has the potential to add value to the phytoplankton monitoring programme and may be automated, enabling the high-throughput screening of wild samples for $D$. acuta and $D$. acuminata. The future culturing of Dinophysis species will make it possible to explore the development of qPCR for this important toxinproducing species.

Acknowledgements The study was carried out as part of the PHYTOTEST project, funded by the National Development Plan (NDP) Marine Institute Strategic Research Program-Advanced Technologies (Project No: AT04/02/02). The authors would like to express gratitude to the FRS, Marine Laboratory, Scotland, for the provision of samples containing Dinophysis cells that were used in this study.

\section{References}

Ahn S, Kulis DM, Erdner DL, Anderson DM, Walt DR (2006) Fiberoptic microarray for simultaneous detection of multiple harmful algal bloom species. Appl Environ Microbiol 72:5742-5749

Altschul SF, Madden TL, Schäffer AA, Zhang J, Zhang Z, Miller W, Lipman DJ (1997) Gapped BLAST and PSI-BLAST: a new generation of protein database search programs. Nucleic Acids Res 25:3389-3402

Anon (2000) LightCycler operator's manual. Roche Molecular Biochemicals, Mannheim
Asai R, Nakanishi K, Nakamura C, Ikebukuro K, Miyake J, Karube I (2003) A polymerase chain reaction-based ribosomal DNA detection technique using a surface plasmon resonance detector for a red tide causing microalga, Alexandrium affine. Phycol Res 51:118-125

Behrenfeld MJ, O'Malley RT, Siegel DA, McClain CR, Sarmiento JL, Feldman GC, Milligan AJ, Falkowski PG, Letelier RM, And Boss ES (2006) Climate driven trends in contemporary ocean productivity. Nature 444:752-755

Bornet B, Antoine E, Francoise S, Marcaillou-Le Baut C (2005) Development of sequence characterized amplified region markers from intersimple sequence repeat fingerprints for the molecular detection of toxic phytoplankton Alexandrium catenella (Dinophyceae) and Pseudo-nitzschia pseudodelicatissima (Bacillariophyceae) from French coastal waters. J Phycol 41:704-711

Bowers HA, Tengs T, Glasgow HB Jr, Burkholder JAM, Rublee PA, Oldach DW (2000) Development of real-time PCR assays for rapid detection of Pfiesteria piscicida and related dinoflagellates. Appl Environ Microbiol 66:4641-4648

Browne R, Deegan B, O'Carroll T, Norman M, Ó'Cinnéide M (2007) Status of Irish Aquaculture, 2006. Marine Institute/Bord Iascaigh Mhara/Taighde Mara Teo, p 113

Coyne KJ, Handy SM, Demir E, Whereat EB, Hutrchins DA, Portune KJ, Doblin MA, Cary SC (2005) Improved quantitative real-time PCR assays for enumeration of harmful algal species in field samples using an exogenous DNA reference standard. Limnol Oceanogr Meth 3:381-391

Doyle JJ, Doyle JL (1987) A rapid DNA isolation procedure for small quantities of fresh leaf tissue. Phytochem Bull 19:11-15

Dybas CL (2006) On a collision course: ocean plankton and climate change. Bioscience 56:642-646

Edvardsen B, Shalchian-Tabrizi K, Jakobsen KS, Medlin LK, Dahl E, Brubak S, Paasche E (2003) Genetic variability and molecular phylogeny of Dinophysis species (Dinophyceae) from Norwegian waters inferred from single cell analysis of rDNA. J Phycol 39:395-408

Evans KM, Bates SS, Medlin LK, Hayes PK (2004) Microsatellite marker development and genetic variation in the toxic marine diatom Pseudo-nitzschia multiseries (Bacillariophyceae). J Phycol 40:911-920

Galluzzi L, Penna A, Bertozzini E, Vila M, Garcés E, Magnani M (2004) Development of a real-time PCR assay for rapid detection and quantification of Alexandrium minutum (a Dinoflagellate). Appl Environ Microbiol 70:1199-1206

Godhe A, Cusack C, Pedersen J, Andersen P, Anderson DM, Bresnan E, Cembella A, Dahl E, Diercks S, Elbrächter M, Edler L, Galluzzi L, Gescher G, Gladstone M, Karlson B, Kulis D, LeGresley M, Lindahl O, Marin R, McDermott G, Medlin LK, Naustvoll L-J, Penna A, Töbe K (2007) Intercalibration of classical and molecular techniques for identification of Alexandrium fundyense (Dinophyceae) and estimation of cell densities. Harmful Algae 6:56-72

Gómez F (2008) Phytoplankton invasions: comment on the validity of categorizing the non-indigenous dinoflagellates and diatoms in European Seas. Mar Pollut Bull 56:620-628

Guillard RRL (1973) Methods for microflagellates and nanoplankton. In: Stein J (ed) Handbook of phycological methods. Culture methods and growth measurements. Cambridge University Press, NY, pp 69-85

Hiney M (1999) The absolute requirement for predictive validation of non-culture based detection techniques. DNA based Molecular Diagnostic Techniques: research needs for standardization and validation of the detection of aquatic animal pathogens and diseases. Report on the Proceedings of the expert workshop on DNA-based Molecular Diagnostic Techniques, Bangkok, Thailand, 7-9 Feb 1999 
Hoorfar J, Malorny B, Abdulmawjood A, Cook N, Wagner M, Fach P (2004) Practical considerations in design of internal amplification controls for diagnostic PCR assays. J Clin Microbiol 42:1863-1868

Hosoi-Tanabe S, Sako Y (2005) Species-specific detection and quantification of toxic marine dinoflagellates Alexandrium tamarense and A. catenella by real-time PCR. Mar Biotechnol 7:506-514

John U, Medlin LK, Groben R (2005) Development of specific rRNA probes to distinguish between geographic clades of Alexandrium tamarense species complex. J Plankton Res 27:199-204

Lassus P, Bardouil M, Truquet I, Le Baut C, Pierre MJ (1985) Dinophysis acuminata distribution and toxicity along the southern Brittany coast (France): correlation with hydrological parameters. In: Anderson DM, White AW, Baden GD (eds) Toxic Dinoflagellates. Elsevier, NY, pp 159-164

Marcaillou C, Mondeguer F, Gentien P (2005) Contribution to toxicity assessment of Dinophysis acuminata (Dinophyceae). J Appl Phycol 17:155-160

Metfies K, Huljic S, Lange M, Medlin LK (2005) Electrochemical detection of the toxic dinoflagellate Alexandrium ostenfeldii with a DNA-biosensor. Biosens Bioelectron 20:1349-1357

Miller P, Scholin C (1998) Identification and enumeration of cultured and wild Pseudo-nitzschia (Bacillariophycae) using speciesspecific LSU rRNA-targeted fluorescent probes and filter-based whole cell hybridization. J Phycol 34:371-382

Moorthi SD, Countway PD, Stauffer BA, Caron DA (2005) Use of quantitative real-time PCR to investigate the dynamics of the red tide dinoflagellate Lingulodinium polyedrum. Microb Ecol 52:136-150

Park MG, Kim S, Kim HS, Myung G, Kang YG, Yih W (2006) First successful culture of the marine dinoflagellate Dinophysis acuminata. Aquat Microb Ecol 45:101-106

Parsons A, Norman M, O'Carroll T, Ó'Cinnéide M (2005) Status of Irish Aquaculture, 2004. Marine Institute/Bord Iascaigh Mhara/ Taighde Mara Teo, p 59
Penna A, Bertozzini E, Battocchi C, Galluzzi L, Giacobbe MG, Vila M, Garces E, Lugliè A, Magnani M (2007) Monitoring of HAB species in the Mediterranean Sea through molecular methods. J Plankton Res 29:19-38

Puel O, Galgani F, Dalet C, Lassus P (1998) Partial sequence of the 24S rRNA and polymerase chain reaction based assay for the toxic dinoflagellate Dinophysis acuminata. Can J Fish Aquat Sci 55:597-604

Saito K, Drgon T, Robledo JAF, Krupatkina DN, Vasta GR (2002) Characterization of the rRNA locus of Pfiesteria piscicida and the development of standard and quantitative PCR-based detection assays targeted to the nontranscribed spacer. Appl Environ Microbiol 68:5393-5407

Sako Y, Hosoi-Tanabe S, Uchida A (2004) Fluorescence in situ hybridisation using rRNA-targeted probes for simple and rapid identification of the toxic dinoflagellates Alexandrium tamarense and Alexandrium minutum. J Phycol 4:598-605

Scholin C, Miller P, Buck K, Chavez F (1997) Detection and quantification of Pseudo-nitzschia australis in cultured and natural populations using rRNA-targeted probes. Limnol Oceanogr 42:1265-1272

Shariff M, Soon S, Lee KL, Tan LT (1999). Practical problems with PCR detection in Asia: the importance of standardization. DNA based Molecular Diagnostic Techniques: research needs for standardization and validation of the detection of aquatic animal pathogens and diseases. Report on the Proceedings of the expert workshop on DNA-based Molecular Diagnostic Techniques, Bangkok, Thailand, 7-9 Feb 1999

Thompson JD, Gibson TJ, Plewniak F, Jeanmougin F, Higgins DG (1997) The ClustalX windows interface: flexible strategies for multiple sequence alignment aided by quality analysis tools. Nucleic Acids Res 24:4876-4882

Zingone, A (2005). IOC taxonimic reference list of toxic plankton algae Dinoflagellates-order dinophysiales. http://www.bi.ku.dk/ioc/group2a.asp 